\title{
About Problems of Interrelation of Regional, Economic and Bank Policy
}

Olga Nikolaevna Vladimirova

\author{
Aida Talyatovna Petrova \\ Gregory Semenovich Gavrilchenko
}

Siberian Federal University, Russia, 660041, Krasnoyarsk, Svobodnij Prospect, 79

\section{Doi:10.5901/mjss.2015.v6n6p91}

\section{Abstract}

The special role in creation of conditions for ensuring the rise in economic growth of the country, the search of reserves for increase of investment and reproduction potential of all sectors of the economy belongs to a banking system. In the article tasks of identification of the main tendencies of development of the regional banking sector and problems of its functioning at the present stage, definitions of interrelation of regional economic and bank policy, development of recommendations about their adjustment are set. The consideration of the theory of evolution of a monetary policy allowed to show a credit role in formation of a gross regional product, to consider non-standard approaches to the solution of problems in the development of a real sector of the economy and to designate the perspective directions of expansion of interaction of banks and a real sector of the economy of the region. The appeal to foreign experience shows the possibility of use of the separate tools which aren't involved in the Russian Federation. The identification of the existing institutional disproportions in quantitative and qualitative parameters, the priority of crediting towards non-productive branches, low levels of indicators of indexes of a financial saturation financial services, savings business, a cumulative index of security of the region with banking services, prove the need of improvement of a legislative base in the field of a monetary policy and a banking system of Russia both on regional, and on federal levels. The authors offer an optimum institutional structure of the regional banking sector.

Keywords: a real sector of economy, a regional policy, banks, gross domestic product, credits, a banking system, a commoditymoney balance.

\section{Introduction}

The strategic objective of the present stage of the development is the creation of conditions for ensuring a rise in the economic growth of the country, the search of reserves for increase of investment and reproduction potential of all sectors of economy, including banks. The special part in the achievement of this purpose is assigned to crediting. In the market economy, the credit relations are the effective mechanism of concentration and a modulation of the capital that is especially important in the solution of the problems connected with the investment and development of the real sector of economy of Russia.

In the conditions of the necessity of transformation of the economy, the role of banks considerably increases, there is a need for maintenance of financial stability of the enterprises, banks, the population, ensuring uninterrupted operation of calculations between economic entities and the direction of investments on development, first of all, of the real sector of economy. The relevance of the consideration of this problem is indisputable amplified in the regional aspect. High concentration in certain regions of the conversion enterprises, the largest industrial giants led to disproportions in the development of regional economies, their high dependence on an economic condition of economic entities. The main trends of regional economic policy are the following:

- a transfer of development centers in the capital of the regions (Moscow, St. Petersburg), the development of production, business, and investments mainly in Moscow and St. Petersburg;

- translation financial flows through the re-registration of companies from the regions to the federal center;

- a high region's dependence on grants and subsidies the federal government, the lack of stability of tax revenues to the regions. In 2013, subsidized from the 83 subjects of the Russian Federation is the subject of 73, the number of which in 2014 added the Republic of Crimea and the federal city of Sevastopol. The number of donor regions reduced - in 2006 there were 20, in 2013 - 10. The volume of regional budget deficit in 2013 amounted to 642 billion rubles. It is the duty of the Russian Federation as on 01.07.2014 was estimated at 1.74 trillion rubles, municipalities -277.4 billion rubles; 
- $\quad$ "patchy development" of economic and social development in the regions - mainly in the development of the regional center and two or three cities and the practical extinction of small towns and villages in the regions (Kondratyev, 2014).

At the same time, the modern geopolitical reality creates numerous calls for a banking system. There were new risks connected with the high level of uncertainty in the world markets and in a political arena. GDP growth was slowed down, the inflation was accelerated, a certain outflow of the capital was outlined, there is a reduction of the volumes of investment, and there is a pressure upon the Russian banking market by the application of sanctions. The Russian banks should get used to a new situation in the economy and to look for new ways of development (Nabiulina, 2014).

\section{Methods}

A chronic commodity-money unbalance, which results into the degradation of the main reproduction proportion, is peculiar to modern Russian economy. The cause of the destruction of a ratio between the sphere of production and the investment sphere is the developed system of the state and oligarchical relations of production acts. The called system assumes a short circuit of the main cash flows on ensuring financial interests of the state, banks and a sector of "oil-gasenergy sales". As a result, a consequence of it is the impossibility of an overflow of the capital out of limits of the abovenamed triangle in the real sector of the domestic economy.

The disputes of economists about a place and role of credits and a financial system in creation of new cost, the added product led to a conclusion: the monetary circulation in this or that form is a system component of a capitalist way of production at all stages of its evolution. However only at a stage of the mixed capitalism there is a nominal sector of the market economy which is regularly providing the real sector with payment and purchasing means. Due to its emergence, in the market economy there was a new public division of labor: there was a financial mediation as a special socially necessary activity in the market economy.

In modern conditions, the interrelation of a monetary turn with the real sector of the economy is mediated by continuous functioning by a two-level credit and a monetary banking system and the developed securities market. The practice showed that both markets - credit and monetary and securities - represent the huge bureaucratic organization with hierarchy of managers of all ranks which is carrying out public bookkeeping and serving the movement of the public capital. Thus the nominal (credit and monetary) sector as the experience testifies, is capable to function irrespectively from real, moreover, to conflict to it. The separation of a nominal sector of the economy from requirements of the real is illustrated by the following fact: it is known that in the USA now the volume of virtual, nothing secured financial transactions is tenfold exceeds the volume in real sector of economy (Lyachin, Gavrilchenko, 2011).

With the division of the market economy into real and nominal sectors, there was a new contradiction: the mixed economy cannot function and develop without an elastic and controlled credit and monetary system. But the credit and monetary system, owing to the independence and own economic interests, possesses the property to come off requirements of the real sector, to enter with its confrontation, what results in the commodity-money unbalance (distortion) and crisis

The evolution of the state economic policy in the countries of mixed economy testifies that in connection with emergence of the nominal sector of economy, which is based on credit and monetary system, the state economic policy develops according to an intensification of interaction of real and nominal sectors of the economy. After World War II the tax and budgetary state economic policy based on the theoretical principles of J. M. Keynes (Keynes, 1919, Keynes, 2012) was implemented. In the 70th years, it is succeeded by the monetary policy, which is based on the monetarist theory of money of M. Fridmen (Friedman, 1962). Since the end of the 80th years the central banks from the refuse application of the last and by the beginning of the XXI century, from analytics of the monetary authorities indicators monetary In the 70th years the monetary policy which is based on the monetarist theory of money of $\mathrm{M}$. Fridmen (Friedman,1962) succeeds. Since the end of the $80^{\text {th }}$ years the central banks refuse from the application of the last and, by the beginning of the XXI century, from analytics of the monetary authorities indicators of monetary units, and the inflation disappear, GDP and unemployment are defined regardless of the monetary offer. As a result, the monetarist form of a monetary policy is replaced by the policy of targeting of inflation (Dolan, Campbell, Rosemary, 1991).

The appeal to theoretical aspects shows that in Keynesian model of regulation of the economy as an object of management cumulative demand in the monetarist - rate of change of the monetary offer (a target reference point of a gain of money supply), in inflationary targeting - a choice of a certain value of a rate of inflation acts as a target reference point for which achievement the management bears the responsibility. Therefore, the conclusion that evolution of forms of the state economic policy is a display of the increase of intensity of interaction of real and nominal sectors of the mixed economy and a way of the permission of the arising contradictions between them is logical. In addition, it needs to be 
considered as the answer to the question - what type of a credit policy is the most adequate to the modern Russian economy.

At the same time, the practice shows that the approaches to the regulation of economy considered above are insufficiently effective, therefore, it is impossible to apply in a pure form any of the listed models of credit and monetary regulation. The priority for the Russian economy -the reproduction and structural economic policy within which various forms of monetary and credit and tax and budgetary policy act as instruments of its realization. Moreover, it mediates an urgent need in the formation of more rational communication and integrity of relationship of a banking system and the real sector of the economy at the regional level - to give the chance to coordinate needs of the economy effectively for banking products and services (Herbert, 1992).

\section{Results}

The realities of the present and results of the economic development confirm a low efficiency of the applied market regulation: release volumes are properly not coordinated to indicators of an expenditure financial, material and a manpower. All reality of production is estimated in rubles, but not in quantity and quality demanded, and products that do not promote a real assessment of efficiency of resources usage.

The bases of the theory of money define participation of credit money in reproduction process. By the present moment among the problems of use of the called resources existing in general in domestic economy and broadcast on regions it is necessary to allocate the following:

- the existence of branch structural disproportions. The key transformation, which is observed as the banking sector in economy of Russia, consists in the advancing growth rates of retail crediting in comparison with the corporate. Actually, if before crisis of 2008 banks stimulated also the offer (crediting corporations), and demand (crediting consumers), after crisis the focus was displaced towards consumer crediting, i.e. stimulation only of demand (Financial Analyst, 2013). According to the Central Bank in a branch section the greatest specific weight is still the share of the credits issued to the enterprises of wholesale and retail trade $(20,1 \%$ on 01.01.2014), and also to the enterprises of the processing productions (20,0\%) (Annual Report, 2014, Report, 2014).

- a steady rise in the price of cost of credit resources which happens in the conditions of the extremely limited growth of economy and business activity. Comparison of the levels of weighted average interest rates on loans to non-financial enterprises in rubles, for a period of 181 to 1 year (Fig. 1), and return on assets and manufactured products businesses shows that there are significant gaps. These average values negate the minimum and maximum levels of interest rates, characteristic for different types of loans. For example, in 2013 the rate on mortgage loans in the Russian Federation was $12.2 \%$, the Siberian Federal District $-12.1 \%$, the Krasnoyarsk Territory $-12.8 \%^{1}$

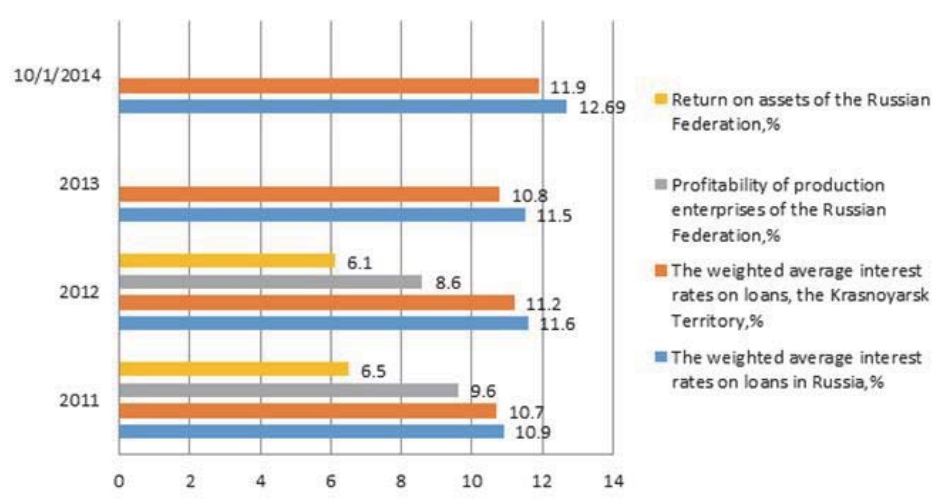

Figure 1. Dynamics of average interest rates on ruble loans to non-financial businesses for a period of 181 days to 1 year, \%

${ }_{1}^{1}$ Official website of the Central Bank of the Russian Federation. [Electronic resource] - URL: http://cbr.ru (date accessed: 01.11.2014) 
Because of the low growth of sales and profitability, it is much heavier to organizations to serve the rising in price credit resources, especially investment orientation. The decrease in a role of the credit as a source of investments into fixed assets is also explained by it. Because of one of the most important features of development of a banking system of Russia during the post-crisis period that the credit participates in production developments less was, but is still the effective mechanism of expansion of domestic demand (Financial Analyst, 2013).

- as a result - the high level of arrears. Arrears volume on the credits to the non-financial organizations for 2012 increased by 14\% that is 3\% higher than an analog of the previous year, in 2013 its value makes 19,2\% (tab. 1). At the same time, the annual growth rate of outstanding debt has outpaced growth in loan debt. In other countries, the corresponding figures are in the range $7-19 \%:-7.9 \%$ in Poland, Serbia $-18 \%,-19 \%$ in Romania, Bulgaria $-17 \%$ (CEE Banking Report, 2013), the average for the euro zone -6.8 \% (Flocking to Europe, 2013).

-uneven concentration of assets of credit institutions (the ratio of assets of the five largest credit institutions in terms of assets to total assets of credit institutions) on the territory of Russia. So, as of 01.11 .2014 of the year for the Central Federal District, the figure is $58.9 \%$, the North-West - $72.9 \%$ of the South $-68.3 \%$, the North Caucasus - $61.4 \%$, Volga - $498 \%$ of the Ural - 70.7\%, Siberian - 78.1\%, Far East - 86.2\%2. In developed European countries, Germany, France, Spain, Italy -in an average of about 40.0\% (CEE Banking Report, 2013), in China -78.6\% (Measuring bank competition in China, 2013). These differences reflect the growing differences between banking groups (state-owned banks, large private banks, medium and small banks in the region of the Russian Federation.

Table 1 - Arrears indicators on the issued credits

\begin{tabular}{|l|c|c|c|c|}
\hline Indicators & $\begin{array}{c}01.01 .2013, \\
\text { billion rubles }\end{array}$ & $\begin{array}{c}\text { Specific weight in } \\
\text { the general debt,\% }\end{array}$ & $\begin{array}{c}01.01 .201 \\
\text {, billion } \\
\text { rubles }\end{array}$ & $\begin{array}{c}\text { Specific weight in } \\
\text { the general debt, \% }\end{array}$ \\
\hline Debt on the credits, all & 33993 & 100 & 40535 & 100 \\
\hline Arrears on the credits & 1257 & 3,6 & 1398 & 3,5 \\
\hline From them: & & & & \\
\hline Debt on the credits to the non-financial organizations & 19971 & 58,7 & 22499 & 55,5 \\
\hline Delayed arrear of non-financial organizations on the credits & 924 & 4,6 & 934 & 4,2 \\
\hline Debt on the credits of natural persons & 7737 & 22,8 & 9957 & 24,6 \\
\hline Arrears on the credits of natural persons & 313 & 4,0 & 440 & 4,4 \\
\hline Portfolio of the credits of small and average business & 4,5 & 16,9 & 5,2 & 15,0 \\
\hline Arrears on the credits of small and average business & 0,321 & 8,42 & 0,343 & 7,1 \\
\hline
\end{tabular}

Source: (Annual Report, 12014)

The introduction of sectoral sanctions against Russian banks and companies from the US, EU and other countries. Direct effect of sanctions is the loss of access companies have come under the sanctions to foreign markets - a source of relatively cheap and long-term funds. The indirect effect of the sanctions associated with the restriction of refinancing foreign borrowing - not only companies that have come under the sanctions, but in some cases, other Russian borrowers, decrease limits on Russian banks even for transactions not subject to the restrictions (swaps and short-term loans), increasing cycle of payments in foreign currency (as a result of the verification procedures of delayed payments lasting from several hours to several days). In addition, foreign rating agencies assign ratings to stop new tools companies fell under the sanctions that restrict issuers in the placement of bonds among institutional investors, are required to make investments in bonds with a rating not below a certain level.

The external debt of the Russian banking sector on October 1, 2014 amounted to \$ 192 billion. US dollars. In the currency structure of external debt of banks, according to the April 1, 2014, is dominated by liabilities denominated in US dollars (70.5\%); the proportion of debt to non-residents denominated in rubles is about $15.3 \%$, in euro - $10 \%$. The main external debt accounts for banks with state participation in the capital (Fig. 2). In this case, the bulk of the planned repayment accounted for more than three years (Fig. 3). ${ }^{3}$

2Overview of the Russian banking sector. (Internet version). №146 December 2014. [Electronic resource] - URL: http://www.cbr.ru/ analytics/bank_system/obs_1412.pdf (date accessed: 01/10/2015)

${ }^{3}$ Financial Stability Review. October 2014 [electronic resource] -URL: http://www.cbr.ru/analytics/fin_stab/ (date accessed: 01.11.2014) 


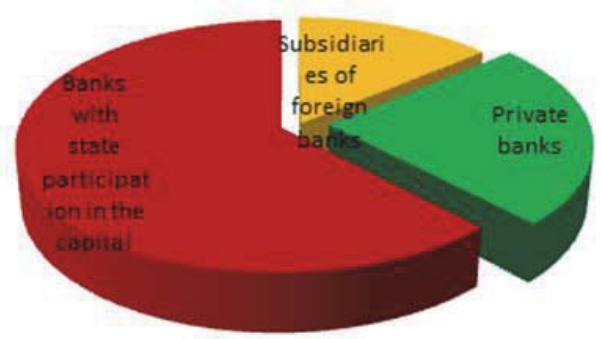

Figure 2 - The structure of external debt in the context of banking sector by types of banks, $\%$

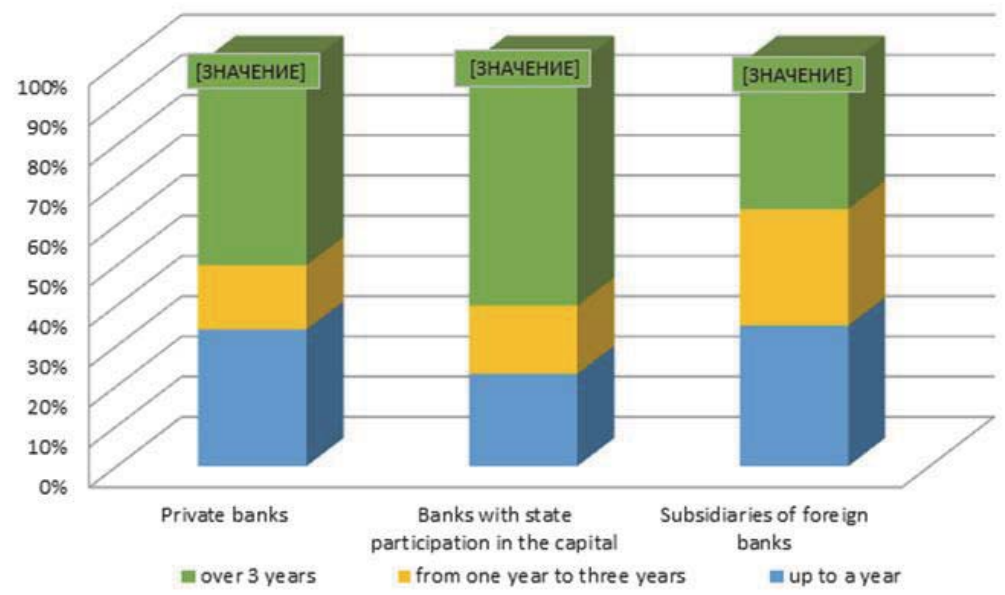

Figure 3 - The term structure of external debt banking sector by types of banks, \%

These factors do not allow our country to raise almost forgotten figure - productivity - and reduce the gap in its level (three times) between Russia and developed countries.

In addition, unlike other countries, Russia is not legally defined priorities and instruments to stimulate lending to the real economy. A significant proportion of funds by domestic banks sent to non-productive sphere, mediation in financial instruments, where the income of the bank provided above, or with less risk than in the reproductive sphere. For example, the states of America had the right to regulate, even prohibiting the opening of bank branches in the territory of another state to avoid capital flight, and if permitted, the specific objective was pursued ${ }^{4}$. China has provided benefits for banks that lend to the real economy and a number of other activities (Chenin, 2013). In the UK, Switzerland and the practice of issuing central bank loans to participants of numerous settlements in one of the payment systems are not limited to the loan amount and interest charges, but with a deposit (the so-called collateral-based system) (Martins, Liguidity,2010). The Swiss National Bank provides the participants of the settlement system SIC-free loans in the form of repurchase agreements (Statistics on payment, 2012).

The external economic instability defines the task of real economic, active state growth at the expense of the internal potential of the Russian economy. It should be noted the fact that the banking system in the market became an independent sector of the economy, carrying on business on a par with other sectors. And this, of course, has a significant influence on the content of statutory goals and objectives of its functioning.

The current monetary policy and the Russian banking system is not until the end of consistent and inconsistent

4The US banking system. Bank of America / M., 2008. [Electronic resource]. URL: http: // www.bankroute.rupage / index / 203 / (date accessed 19/09/2014) 
with the opinion of some experts regarding the challenges of economic growth and development.

At present, the domestic banking system is going through a difficult period. Conducted by the Central Bank in order to increase the efficiency of the banking activities of modernization of the institutional structure of the whole country, has a negative impact on the regions. The territorial and national control cash settlement centers are in the abolished structure of the first level of the banking system, larger commercial banks in the structure of the second level are closed, merged. With the current ineffective structure of the banking system held by the Bank of Russia conversion, in our opinion does not improve it, and further exacerbates the problem of availability of financial resources for commercial banks, in particular, this is true for regions with a large area and territorial extent.

Let us illustrate the above with an example of a particular region - the Krasnoyarsk region. The Krasnoyarsk region is one of the largest regions of Russia: the total area occupies the territory of 2.34 million sq. m. km (2nd place in Russia), has a population of 2.9 million people (13th place), the length of 3 thousand $\mathrm{km}$ from the shores of the Arctic Ocean to the mountainous regions of southern Siberia. The Krasnoyarsk region occupies $46 \%$ of the Siberian Federal District, accounting for $14.8 \%$ of the population. The region has access to the Northern Sea Route. The Krasnoyarsk Territory is one of the top ten donor regions, forming more than $40 \%$ of Russia's GDP and the federal budget. The region has a high economic potential: $2 \%$ of the population of Russia create $2.6 \%$ of GDP and $3.3 \%$ of industrial production in Russia (Regions of Russia, 2013).

On 01.07.2014, there is the structure of 33 commercial banks ${ }^{5}$ in the region, of which only three banks are registered and have parent banks in the region. There small banks have little affect on the economy. The remaining 30 banks are registered, mainly in the central cities of Russia, and in the economy of the region operate their internal departments: 900 additional offices, operational cash, credit and cash offices, operational offices - all of which have no rights and are not liable in the region. Their main task is to attract financial resources of businesses and individuals, as well as issues of lending only within specified limits bank's head office, which is usually minimal. The possibility of granting a large loan determines the parent bank (outside), which has no direct interest in the development of the region.

Considering the efficiency of the banking system through the lens of statistics providing banking services to the Siberian Federal District and the Krasnoyarsk region, it can be concluded that there was insufficient, uneven distribution of banking services and funds (financial resources) (Table 2). And this situation is mainly typical for by counties located outside the European part of the country.

Table 2 - Indicators of providing banking services

\begin{tabular}{|c|c|c|c|c|c|c|c|c|c|c|}
\hline \multirow{2}{*}{ Indicators } & \multicolumn{2}{|c|}{$\begin{array}{c}\text { Central Federal } \\
\text { District }\end{array}$} & \multicolumn{2}{|c|}{$\begin{array}{c}\text { North-West } \\
\text { Federal District }\end{array}$} & \multicolumn{2}{|c|}{$\begin{array}{l}\text { Urals Federal } \\
\text { District }\end{array}$} & \multicolumn{2}{|c|}{$\begin{array}{c}\text { Siberian } \\
\text { Federal District }\end{array}$} & \multicolumn{2}{|c|}{ Krasnoyars Krai } \\
\hline & 2013 & 2014 & 2013 & 2014 & $\begin{array}{c}201 \\
3\end{array}$ & 2014 & $\begin{array}{c}201 \\
3\end{array}$ & 2014 & $\begin{array}{c}201 \\
3\end{array}$ & 2014 \\
\hline Saturation index of institutional banking services & 1,05 & 1,02 & 1,14 & 1,13 & 1,11 & 1,12 & 0,96 & 0,97 & 1,15 & 1,13 \\
\hline $\begin{array}{l}\text { Financial Index saturation financial services } \\
\text { (consumer lending) }\end{array}$ & 1,29 & 1,25 & 1,08 & 1,05 & 0,59 & 0,64 & 0,94 & 0,94 & 0,8 & 0,76 \\
\hline Development Index savings business & 1,43 & 1,42 & 1,14 & 1,13 & 0,76 & 0,76 & 0,7 & 0,7 & 0,63 & 0,66 \\
\hline $\begin{array}{l}\text { The aggregate index of security of banking } \\
\text { services in the region }\end{array}$ & 1,25 & 1,22 & 1,12 & 1,10 & 0,79 & 0,81 & 0,86 & 0,86 & 0,84 & 0,83 \\
\hline
\end{tabular}

Compiled by: (Annual Report, 2014)

One of the most important is the indicator of institutional banking services saturation regions, calculated as the ratio of the number of credit institutions (the number of points of banking services) in the region (credit institutions, branches, and additional operational offices) to its population. In the Krasnoyarsk region institutional saturation is observed. The structural imbalance is obvious: for servicing and lending companies, mining minerals, we need big banks, for the processing industry - the average, and for agriculture and retail - small banks. Table 3 shows the optimal institutional structure of the regional banking sector according to the method proposed Petrova T.I. (Petrova, 2010). 
Table 3 - A Model of optimal institutional structure of credit institutions, \%

\begin{tabular}{|c|c|c|c|c|c|}
\hline Federal District & Size of business & $\begin{array}{l}\text { The proportion of the total } \\
\text { number of business entities }\end{array}$ & Type of credit institution & \begin{tabular}{|l|} 
Current portion the \\
total number of \\
credit institutions, \%
\end{tabular} & $\begin{array}{l}\text { Optimal share in the } \\
\text { total number of } \\
\text { credit institutions, \% }\end{array}$ \\
\hline \multirow{2}{*}{$\begin{array}{l}\text { Siberian } \\
\text { Federal District }\end{array}$} & $\begin{array}{l}\text { Large and medium-sized } \\
\text { enterprises }\end{array}$ & 33,74 & \begin{tabular}{|l|} 
Large banks, banks etc. \\
Regions
\end{tabular} & 90,8 & 63,74 \\
\hline & \begin{tabular}{|l|} 
Small businesses and \\
individual entrepreneurs
\end{tabular} & 66,26 & $\begin{array}{l}\text { Medium and small } \\
\text { banks, NGOs }\end{array}$ & 9,92 & 36,26 \\
\hline
\end{tabular}

The obtained data illustrate that there are significant gaps between the actual number of credit institutions and the optimum proportion of the total number of banks to service the large, medium and small organizations and individual entrepreneurs:

- large and medium-sized enterprises $90.8 \%$ service large banks, with optimum performance $63.74 \%$;

- the share of small businesses and individual borrowers is $66.26 \%$, and the service is only $9,92 \%$ of the banks, at the optimal norm $36.26 \%$.

The inconsistency of quantitative and qualitative parameters of the banking system to the needs of business entities in the region leads to incomplete credit and slower calculations. Unfortunately due to the total assets of banks in the country of 70 trillion rubles participates in investment projects less than one percent. According to official statistics, the organization of the Krasnoyarsk Territory (excluding small and medium-sized enterprises) in 2014 from January to November was used 235.5 billion rubles of investments in fixed capital, which is $87 \%$ the same period in 2013 (in 2013 to $98.2 \%$ in 2012). All organizations of the region in 2014 received 344.5 billion rubles of investment, which is $12.1 \%$ less than the 2013 banking share of investment in fixed assets accounts for only 7-9\%.

Thus, the current structure of the banking sector does not meet the needs of the region economy.

The level of financial saturation indices by financial services (determined based on the volume of loans in relation to the gross regional product) development savings business (calculated based on the volume of deposits falling per capita, per capita income in the region is an indication of the financial activity of citizens, demonstrates the level of interest and people's confidence in financial institutions), and, consequently, the overall index provision of banking services in the region (calculated as the geometric mean of the three indices of private security) in relation to the dynamics of the subjects in question is lower than in the Russian Federation, and is significantly lower than in the central districts. This can partly be explained by the spatial dimension - the area of subjects included in the Urals, Siberia, the Far Eastern federal districts together make up $76.8 \%$ of the Russian Federation. The unevenness of their settlement, long distances between settlements (especially in the northern part) predetermine the limited opportunities of access to financial services provided by credit institutions in contrast to the subjects of the Central, Northwestern Federal District. The spatial characteristics undeniably must be taken into account when reforming the banking infrastructure in the regions.

The proof of the official statistical analytical data are the results of empirical studies based on the overall index of the banking system in the region, which allows us to give a comprehensive assessment of the banking systems of the region (institutional, economic development, financial services saturation region). The Krasnoyarsk region to the level of the index 6.85 percentage points is included in the group of underdeveloped regional banking systems, including 32 in the region and are characterized by the predominant operation of small regional banks (Figure 4) (Rykov, Fissenko, 2012). 


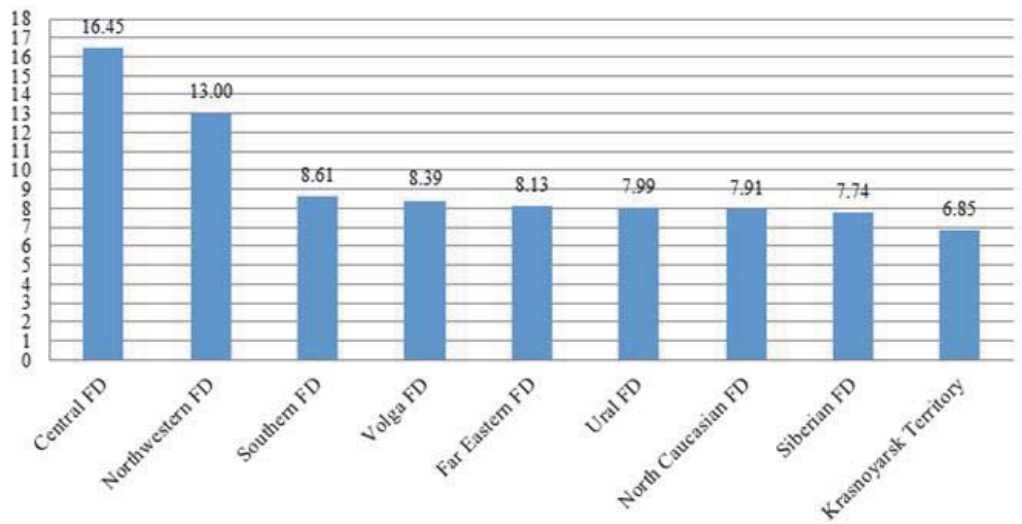

Figure 4.The Ranking of the banking systems of Federal Districts and the Krasnoyarsk Territory on the value of the overall index. Source (Rykov, Fissenko, 2012)

The development of the banking sector of the Krasnoyarsk Territory in 2014 comes in a slowing flow of resources from all sources of attraction, except for deposits of legal entities and slowing credit growth. The total loan portfolio in the first half of 2014 rose to $108.8 \%$, and for the first half of 2013. - 121.1\%. Loans to individuals decreased their share in the total loan portfolio was $43.1 \%$ (in $2013-46.2 \%$ ) The volume of loans to individuals by $25.2 \%$ higher than the volume of deposits (in 2013 - 20\%). The quality of the loan portfolio of commercial banks by evaluation of the Bank of Russia for the Krasnoyarsk Territory remains satisfactory. But arrears borrowers for the first half 2014 increased by $26.9 \%{ }^{6}$

Nowadays own cash resources of businesses and individuals in the region are of paramount importance due to reduced foreign investment. The overwhelming majority is $89.4 \%$ of the region resource base is still concentrated in the branch network of credit institutions of parent banks, which are located in other regions.

All funds of enterprises, organizations, population of the region, except for the budget are on the balance sheets of commercial banks outside the region, non-interested to invest in the real sector of the economy of the region. And the explanation of this fact is quite simple: in accordance with the provisions of the Federal Law "On Banks and Banking Activity" the purpose of commercial banks is profit.

The results of the analysis of federal and regional regulatory low base confirm the absence of a regional banking policy. Today, unfortunately, has no relevance the question - how many banks in the region, and to what extent the amount of cash flow meets the needs of the region's economy. This form of regulation is not entirely effective, requires the intervention of the state and the region in cash flow management.

The weakening of national attention to this issue is obviously temporary. However, the realities of regional development require enhanced action on the part of the regional leadership, as well as the National Bank of Russia in the regional, provincial and district centers, which are closed by Central Bank at this stage.

The first level of the banking system is released from interlink ages with the activities of the real economy completely. Available reports do not reflect the return on investment in the development of industry-implemented forms of ongoing monitoring, data collection methods, which cannot withstand any criticism.

The Bank Russian commercial globalization of the banking sector to a greater extent, has a negative value for the region, having a large area. The lack of financial resources is not compensated adequately the leading banks outside the region. The main reasons are a weak (insufficient) resource base in the banking system, and most importantly - the lack of interest from commercial banks to invest credit funds in the real economy in general, and in the innovation process in particular.

At this level, we emphasize the market mechanism works poorly, so the design is seen in increased use of instruments such as plans, guarantees provided by the state.

The second level of the banking system is commercial banks, they "distribute" the money. Their mission is to ensure the repayment of the loan and interest for it, respectively, and the goal is to get more from a borrower, and not how to help him. The partnership in most transactions is not present. If there are arrears banks are willing, at times, and

${ }^{6}$ Official website of the Central Bank of the Russian Federation. [Electronic resource] -URL: http://cbr.ru (date accessed: 01.11.2014) 
"crush" - to sell under the hammer of the borrower, and return their money, but is it theirs?

The lack of an adequate regional monetary policy on the part of the regulator - the Bank of Russia adversely affects the velocity of money in the region, hence the socio-economic and innovation and investment development. The development of innovations is under way by a point method, and in these conditions it is impossible to balance the innovation and investment policy in the region (Vladimirova, Gavrilchenko, 2014).

The banking sector should provide cash production and not blindly go for a large percentage. The action is needed to improve the efficiency of the credit rate. Therefore it seems logical and possible to return to proven methods of control in determining performance. For example, in earlier times there was a part of the banking system as a service engineering control efficiency of financing road construction. A banking engineer at a construction site was been afraid. There were constant control measurements: if standard provides a cushion thickness of thirty centimeters of a soil or asphalt, and laid only 28 centimeters, then for the missing $9.3 \%$ shortfall of works from the norm is removed from the amount of funding for the area of poor performance. Similar forms can be implemented currently - and balance indicators to the value of the interest rate for the loan, and pay.

\section{Conclusion}

The restoration of the commodity-money balance of real and nominal sectors of the Russian economy requires no maximum withdrawal of the state from the economy, but rather its active participation in the management of the expanded reproduction. This is possible with creating the country's reproductive mechanism of monetary circulation, allowing to achieve the unity of the industrial, scientific, technical, structural, and monetary policy, changing priorities emission rubles for foreign currency in the direction of emission of rubles on the demand for money by the domestic economy.

The articles of the law "On Banks and Banking", unfortunately, are not guided by commercial banks to operate on the basis of public interest, do not impute responsibility for the development of the real sector of the economy and the interests of the region. It is necessary to change the direction of credit, to create a priority lending to the real economy, especially import-substitution to stimulate public support issuance of preferential loans for the purchase of cattle and sheep for the development of animal husbandry, etc. It is important to pay attention to the development of processing industries in agriculture and other industries.

We consider it appropriate to recommend to the Central Bank of the Russian Federation to extend the technique to its essential function to strengthen the stability of the ruble (Art. 75 of the Constitution of the Russian Federation). You must create a system of incentives interests of commercial banks for lending to the real sector of the economy, including the priority areas of the economy. You can use the experience of China and other countries, where there are available facilities in the interest rate policy or taxation.

The concentration of banking resources in the regional centers of the country, forces, in our opinion, to create a special body constant search of free resources for investment projects in the region.

The next problem in the banking system is "short-term" financial resources. In this regard, in particular, it is proposed to extend the model of the Central Bank refinancing. At present, the only model the Bank of Russia "in the short term aligns some distortions" that appear in the banking sector.

Obviously, the best time of imitation to often barely holding its position countries have passed and it is necessary to develop and transfer to the Russian system - balanced - commodity-money. The banking system is the only one in the country that can organize the transparency of the total money turnover of business entities and the public, to show the direction of investments and their efficiency, control and regulate the circulation of money, not a substitute for the rights and legitimate decisions of business owners.

\section{References}

Kondratyev A. Regional Development: Problems and Prospects // The Economist. - 2014. - №2. - p. 82-91. https://www.mgpu.ru/ materials/9/9767.pdf

Nabiulina E.S. - Speech by President of the Bank of Russia and the participants Banking Congress, St. Petersburg // Money and credit 2014. - № 8. - C. 6-10. http://www.budgetrf.ru/Publications/Magazines/VestnikCBR/2014/ves140709063/ves140709063.pdf

Lyachin V.I., Gavrilchenko G.S. Problems of commodity-monetary balance in the reproduction of relations of social market economy. Monograph. // Krasnoyarsk, Sib. Gos. Aerospace University, 2011. - 160 p. http://www.gutenberg.ca/ebooks/keynes-means/ keynes-means-00-h.html

Keynes, J.M. http://gutenberg.ca/ebooks/keynes-means/keynes-means-00-h.html // The Economic Consequences of the Peace, 1919.

Keynes, John. The General Theory of Employment, Interest and Money / Trans. prof. N.N. Lyubimov. - M.: Helios ARVs, 2012. - 352 p. 
http://lib100.com/book/other/general_theory_employment/\%c4\%e6\%ee\%ed\%20\%

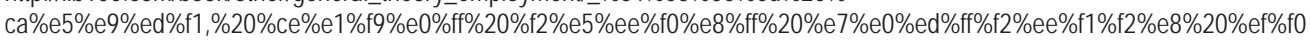
\%еe\%f6\%е5\%ed\%f2\%е0\%20\%е8\%20\%e4\%е5\%ed\%e5\%e3.pdf

Friedman M. Capitalism and Freedom Chcago: University of Chicago Prees, 1962. http://gtmarket.ru/files/book/milton-friedmancapitalism-and-freedom.pdf

Edwin J. Dolan, Colin J. Campbell, J. Rosemary. Campbell Money, Banking, and Monetary Policy. Money, banking and monetary policy. Translated from English. Lukashevich V.V. // Ed. PFC "Profikom", M. 1991. - 245 p. http://www.bntu-Ig.by/files/admin/books/ debgi_BD.pdf

Simon Herbert // Nobel Laureate: Universal scientific and popular "Encyclopedia Krugosvet", Economics and Law. M-I: pens. from English. M., 1992. - 347 p.

The role of banks in the socio-economic development of Russia // Financial Analyst, problems and solutions. -2013. - № 27 (165) -C. 4450. http://www.fin-izdat.ru/journal/fa/detail.php?ID=57672

Annual Report of the Central Bank of the Russian Federation for 2013 // M.: LLC "Printing Revival". - 2014. - 281 p. http://www.asros.ru/ public/files/8/7540-godovoiotchettsbrf_2013.pdf

Report on the development of the banking sector and banking supervision in 2013 // M.: 000 "Typography Paradise." - 2014. - 128 p. http://www.cbr.ru/publ/archive/root_get_blob.aspx?doc_id=9525

CEE Banking Report: Commitment will be rewarded // Raiffeisen Research 2013. May. 88 p. http://www.raiffeisen.ro/en/press/ceebanking-sector-commitment-will-be-rewarded

Flocking to Europe: Ernst\&Young 2013 non-perfoming loan report. Ernst\&Young. 30 p. http://www.ey.com/GL/en/Newsroom/Newsreleases/News_Could-Europe-be-next-major-destination-for-investors-in-non-performing-loans

Measuring bank competition in China: a comparison of new versus conventional approaches applied to loan markets// BIS Working Papers.2013. August. № 422.62 p. http://www.bis.org/publ/work422.pdf

The banking system of the United States. Bank of America / M., 2008. (Electronic resource). URL: http: // www.bankroute.rupage / index / 203 / (date accessed 19/09/2014).

Chenin R.K. Banking systems around the world Textbook / KNORUS, 2013. - 400 p. http://www.knorus.ru/upload/pdf/267643.pdf

Jugilas M. Martins A. Liguidity-Saving Mtchanisms in Collateral - Based RTGS Payment Systems // FRBNY Staff Reports. 2010. 438. P. 3. http://www.newyorkfed.org/research/staff_reports/sr438.pdf

Statistics on payment, clearing and settlement systems in the CPSS countries -Figures for 2012. BIS.2013. P. 586. http://images. derstandard.at/2012/04/26/Statistics\%20on\%20payment,\%20clearing\%20and\%20settlement\% 20systems\%20in\%20the\%20CPSS\%20countries.pdf

Regions of Russia. Socio-economic indicators. 2013.: Stat. Sat / Rosstat. - M., 2013.-990 p. http://virtua. nsuem.ru/mm/2014/0002 02778.pdf

Petrova T.I. The optimal model of the institutional structure of the banking sector in Russia // Banking delo. - 2013. - № 8. - P. 62-68.

Rykov I.N., Fissenko N.V. Comprehensive assessment of the level of development of the banking systems of the region // Banking. 2012.-№4. - p. 23-29. http://www.fa.ru/institutes/efo/Documents/BD04_2012_Rycova.pdf

Vladimirova O.N., Gavrilchenko G.S. Problems balanced development of innovation and investment activities of the regional economic system // Scientific Review. - 2014. -№9. - P. 562-568. 